\title{
Heavy rainfall: An underestimated environmental risk for buildings?
}

\author{
Sebastian Golz ${ }^{1, a}$, Thomas Naumann ${ }^{1}$, Marco Neubert ${ }^{1}$, Benno Günther ${ }^{2}$ \\ ${ }^{1}$ Leibniz-Institute of Ecologic Urban and Regional Development, Weberplatz 1, 01217 Dresden, Germany \\ ${ }^{2}$ GB1 Engineers - Office for Buildings, Building Constructions and Damage Analysis, Friedrich-Hegel-Str. 29, 01187 Dresden, Germany
}

\begin{abstract}
Although impacts of heavy rain on buildings in urban areas are often extensive, the public usually underestimates the negative consequences of that environmental risk compared e.g. to storm or hail events. However, the intensification of extreme weather events due to climate change as well as the rising physical vulnerability of assets are going to trigger the increase of impacts on the built environment. Heavy rain events are often highly localised that makes it difficult to estimate their probability and magnitude accurately. High intensity rain affects buildings both directly as well as indirectly.

First, engineering surveys have already proven the broad variety and high physical vulnerability of building constructions that are directly and frequently affected by invading water during heavy rainfall events: flat roofs, roof terraces and balconies, connections between steep roofs and other building parts, soil-covered slabs of underground parking, soil-contacted basement walls and bottom plates as well as windows and external doors. It became evident that most damage is avoidable if exposed constructions become more resilient. Nevertheless, any adaptations require expertise on the demanding damage processes in order to explore deficiencies and to reduce physical vulnerability of building constructions exposed to heavy rainfall. In response to that challenge, the paper describes an engineering approach for the systematic classification of physical vulnerability criteria based on empirical research. A developed classification scheme allows the ex-ante examination of typical failure modes and the evaluation of negative consequences of heavy rainfall at individual building level. The topic is of high relevance, because the classification scheme may act as a capable tool for the prospective planning of adaptations towards more resilient buildings.

Second, heavy rain may result in urban pluvial flooding due to sewer overflow that cause severe damage to buildings. A comprehensive study of the impacts and the consequences in Dresden (Germany), presented in the paper, revealed that the potential risks of flooding from sewers due to hydraulic overload can be estimated on building scale using the model approach IVART (Integrated Spatial Vulnerability and Risk Assessment Tool). Modelling results provide the basis to quantify the effectiveness and efficiency of flood resilience technologies.
\end{abstract}

\section{Introduction}

Global climate change is detectable and the projections of its prospective regional impacts are critical for any adaptation planning. It became obvious that particularly the probability and magnitude of hazardous heavy rain events have been increasing in several European regions within the last 40 years (Grieser and Beck 2002). Against this background, the paper asks (i) how to analyse the negative consequences for buildings and (ii) how to describe and reduce the resulting risk. The negative consequences of heavy rain depend on the physical vulnerability of buildings, i.e. on the potential of exposed materials and structures (e.g. roofs, façade) to be harmed and to suffer damage.

The adaptation of existing buildings is challenging due to the complexity of heavy rain impacts. Exploring those impacts in detail is a prerequisite to develop adequate adaptation measures. Within the collaborative research project REGKLAM, funded by the German Feder- al Ministry of Education and Research, six extreme weather conditions have been analysed based on the climactic situation in the sample region of Dresden (Saxony): summer heat, flooding, heavy rain, hail, storm, and snow. In particular, hazardous heavy precipitation events will become more frequent, widespread and intense in the next decades. Therefore, this paper focuses on the impacts of heavy rain, including moisture damage as a major negative consequence, in order to develop a method for the classification of the physical vulnerability of building constructions.

\section{Heavy rain impacts on buildings}

Heavy rain events are often highly localised. It is therefore difficult to establish their probability and magnitude accurately, as the most intensive rain may not have been sampled reliable by the available rain gauges. Based on the research in REGKLAM, a meteorological survey of the climate development in Saxony was conducted

\footnotetext{
${ }^{a}$ Corresponding author: $\underline{\text { s.golz@ioer.de }}$
} 
incorporating collected meteorological data from the past decades (1961-2005) (Bernhofer et al. 2009). The survey proofed the increase of the annual medium precipitation in the Dresden area that experienced heavy rainfall e.g. in August 2002 at rates of around $160 \mathrm{~mm} / 24 \mathrm{~h}$ (recurrence interval of about 1 in more than 100 years).

With regard to the prospective amounts of rainfall, according to Bernhofer et al. (2011), a decrease in rainfalls is to be expected during the summer period and an increase during the winter period. Although it is rather difficult to predict future extreme precipitation events based on climate projections, trend analyses carried out in this region point to a likely increase of heavy rains, in terms of both intensity and the probability of their occurrence (Franke and Bernhofer 2009).

\section{Standards and codes}

\subsection{Impact parameters}

Germany's National Meteorological Service, the Deutscher Wetterdienst (DWD), defines the intensity of rainfall as the ratio of the total amount of rain (rainfall depth) falling during a given period to the duration of the period. The rainfall intensity is expressed in depth units per unit time, usually as $\mathrm{mm}$ per minute $(\mathrm{mm} / \mathrm{min})$ or $\mathrm{mm}$ per hour (mm/h). DWD (2013) classify the rainfall intensity according to the precipitation rate. Heavy rain events are often temporally and spatially confined and specified by the following precipitation thresholds:

- precipitation $>5 \mathrm{~mm} / 5 \mathrm{~min}$,

- precipitation $>7,1 \mathrm{~mm} / 10 \mathrm{~min}$,

- precipitation $>10 \mathrm{~mm} / 20 \mathrm{~min}$ and

- $\quad$ precipitation $>17,1 \mathrm{~mm} / 60 \mathrm{~min}$.

In contrast, very heavy rain is characterized by

- precipitation $>25 \mathrm{~mm} / 60 \mathrm{~min}$ and

- $\quad$ precipitation $>35 \mathrm{~mm} / 360 \mathrm{~min}$.

However, these thresholds vary considerably between different classification schemes.

The key climate-related parameters of heavy rain impact that play a role in civil engineering are the design rainfall intensity and the wind-driven rain (WDR) load. Particularly the latter has been identified as the most important moisture source that affect e.g. the hygrothermal performance and the durability of building façades or lead to interior damage due to water penetration (e.g. Baheru et al. 2014, Kubilay et al. 2014, Nik et al. 2015). WDR is rain that is given a horizontal velocity component by the wind and that falls obliquely (Blocken and Carmeliet 2004).

Corresponding standards and codes contain characteristic values for both parameters. They depend on e.g. the geographical location and the height of the building. The classification of the design rainfall intensity bases on a statistical analysis incorporating precipitation totals, the duration and the return period. The design rainfall intensity establish a basis parameter for the dimensioning of drainage facilities and the implementation of any specifications for the roofing and the water proofing of exposed constructions. Design rainfall intensities can be looked up e.g. in specific standards (DIN 1986-100) or in the KOSTRA database of the DWD (2005). In the case of façades and their construction elements, the strains caused by heavy rain are of particular relevance. According to DIN 4108-3, the building's location results in three different stress groups according to wind-driven rain protection of external walls; windows and doors, on the other hand, wind-driven rain protection is established in accordance with to DIN 18055, which involves the height of the building.

\subsection{Building element requirement}

Because of the concentrated demands in these areas, heavy rain impacts are mainly considered in planning and dimensioning algorithms for roof and façade constructions. As for roofing, the generally accepted construction techniques are currently laid down in the rulebook of the Deutsche Dachdeckerhandwerk (ZVDH 2011) and within the specialist rules of the ZVSHK (2009). Unutilised roofs with sealing and extensively greened roof areas fall under the jurisdiction of DIN 18531. As far as utilised and/or intensively greened roof areas as well as balconies and roof terraces are concerned, DIN 18195-5 contains the required specifications, though the guidelines of the ZVDH (2009) regulations for flat roofs must be taken into account.

The measuring of roof drainage need to be carried out according to methods of sampling and detection laid down in DIN EN 12056-3. In addition, additional assessment principles regarding the required design rain intensities are to be found in DIN 1986-100. Inspection and maintenance cycles of roof drainage systems are laid down in DIN 1986-3. As to the planning, measuring and execution of windows, doors, and curtain walls, there are a multitude of norms and regulations. In connection with heavy rain impacts, special attention must be paid to DIN 18055, DIN 18355, DIN EN 12208, DIN EN 12154 as well as the manual on planning and execution for the fitting of windows and external doors of the Quality Control Association (RAL 2006).

\section{Physical vulnerability classification}

The prime objective of this paper is to establish the cause and the effect of heavy rain by empirical research. The developed physical vulnerability classification bases on a systematic survey and analysis of 65 buildings that experienced damage by heavy rain. According to the current state of knowledge, this survey encompass all relevant damage types and damage mechanisms (MNI 2012). The survey supported the identification of the most susceptible building constructions exposed to heavy rain (Figure 1). 
Table 1. Standards and codes for the professional design of building constructions exposed to heavy rain.

\begin{tabular}{|c|c|c|c|c|}
\hline \multirow[t]{2}{*}{ Impact parameters } & \multicolumn{4}{|c|}{ Building element requirements } \\
\hline & Steep roof & $\begin{array}{l}\text { Flat roof, } \\
\text { roof terrace, balcony }\end{array}$ & $\begin{array}{l}\text { Façades, windows, } \\
\text { doors }\end{array}$ & $\begin{array}{l}\text { Soil-contacted ele- } \\
\text { ments }\end{array}$ \\
\hline Design rain intensity: & Roofing: & $\begin{array}{l}\text { Water-proofing of } \\
\text { non-utilised roofs: }\end{array}$ & External walls: & Water proofing: \\
\hline $\begin{array}{l}\text { KOSTRA-DWD } \\
\text { DIN 1986-100 }\end{array}$ & $\begin{array}{l}\text { Regulations of the } \\
\text { German Roofing Trade } \\
\text { (ZVDH 2011) }\end{array}$ & DIN 18531 & DIN 4108-3 & DIN 18195 \\
\hline Wind-driven rain load: & & $\begin{array}{l}\text { Water-proofing of } \\
\text { utilised roofs, balco- } \\
\text { nies, roof terraces: }\end{array}$ & Windows, doors: & WU Elements: \\
\hline \multirow{3}{*}{$\begin{array}{l}\text { DIN 4108-3 } \\
\text { DIN } 18055\end{array}$} & Specialist rules of the & & DIN 18055 & WU Guideline of the \\
\hline & & $\begin{array}{l}\text { In each case valid: } \\
\text { Guideline for flat } \\
\text { roofs of the ZVDH }\end{array}$ & $\begin{array}{l}\text { Manual planning and } \\
\text { construction (Quality } \\
\text { Control Association } \\
(\text { RAL 2006)) }\end{array}$ & \\
\hline & $\begin{array}{r}\text { Roof-d } \\
\text { DIN EN } \\
\text { DIN } 19\end{array}$ & $\begin{array}{l}\text { nage: } \\
2056-3 \\
5-100\end{array}$ & $\begin{array}{l}\text { Curtain walls: } \\
\text { DIN EN } 12154\end{array}$ & \\
\hline
\end{tabular}

\subsection{Damage types and damage mechanism}

As a rule, building damage caused by heavy rain present themselves as the sum of individual cases which are often cleared by a multitude of individuals and which are monetarily compensated. This is the reason why these damages often remain invisible to the public eye, unlike the severe damage caused by floods, storm or hail impacts. They are thus only rarely recognized to be related events.

Typical damage profiles caused by heavy rain include moisture penetration, water stains and efflorescence on inner building elements, as well as water influx through the building shell (Zimmermann et al. 2008). These incidents are often accompanied by damages to the fabric of the building and immediate use restrictions of individual components or of whole sections of the building, respectively. The economic consequences, which these effects bring about often amount to much more than the mere efforts required to remove technical and optical inconveniences.

Using the example of the two elements "flat roofs" and "balconies and roof terraces" which are frequently affected by heavy rain damages, the following table 2 gives an overview of all significant damage causes which were relevant within the case study in the region of Dresden. Similar results were obtained for all the construction elements of the fabric of the building. They can form the basis for a systematic survey of the vulnerability of existing buildings to heavy rain impacts.
Due to lack of drainage for unscheduled present moisture in the building elements, moisture often shows a long-term impact and can cause the material properties to deteriorate, sometimes resulting in a loss of the bearing capacity of building components. Static problems can be caused by pest infestation of constructions made of wood, or by corrosion of steel components and concrete reinforcement. When materials, which are sensitive to moisture such as gypsiferous materials, mineral thermal barrier coatings or wood composites, are loaded with moisture, the damage is often irreversible, and the constructions need to be completely replaced. The damage cases, which were examined required significant structural measures as a rule; the costs were accordingly high. Often, the constructions in question had to be modified, too, in order to minimize the future damage risk.

\subsection{Vulnerable building elements}

The survey showed that the impact of heavy rain on buildings brought about damages with frequently identical or at least comparable causes and mechanisms for buildings from the same age group and, by implication, of comparable constructions. This means that specific components, which contribute to the damage can be identified, which allows for comparability and assessment. The following figure shows the particularly relevant components of the fabric of the building (for buildings erected after 1990), which were identified over the course of the survey. 


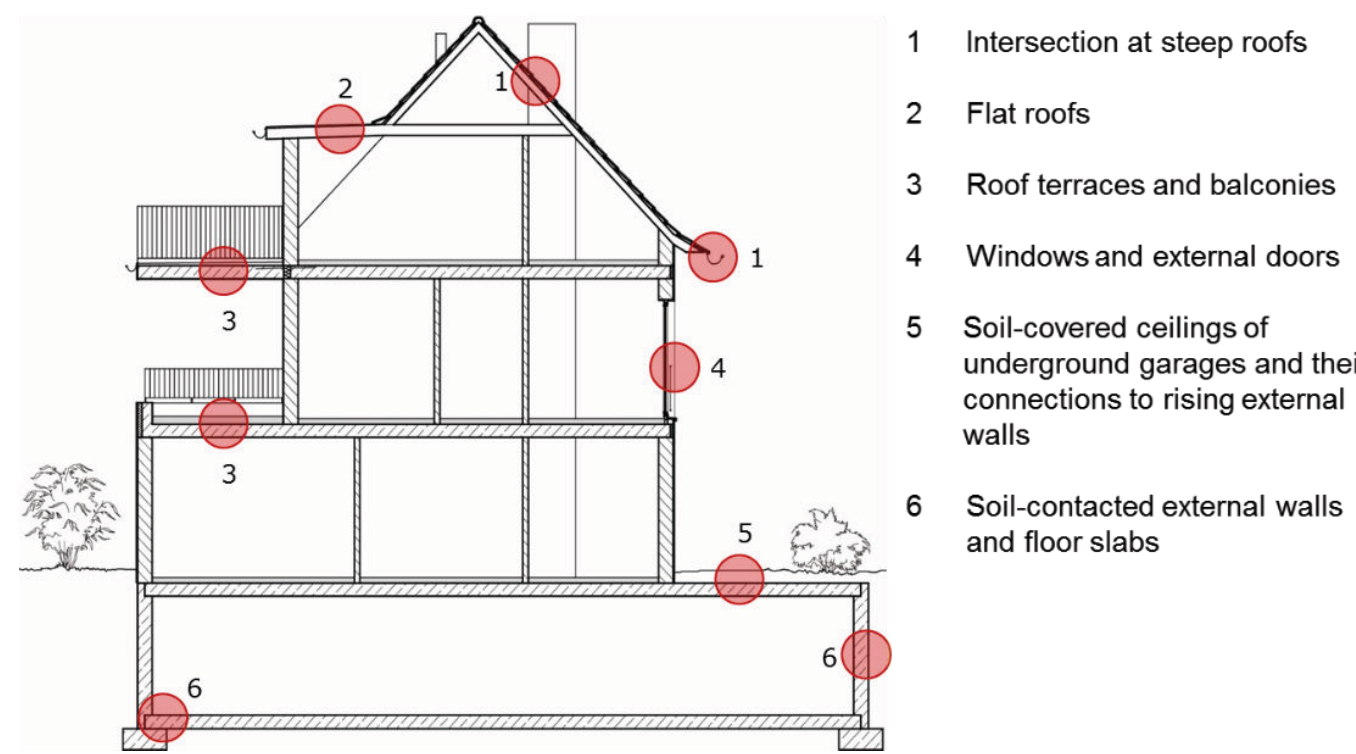

Figure 1. Typical damage areas due to heavy rain impacts. The results base on a survey of residential buildings and non-residential buildings erected later than 1990 .

Steep roofs are characterised by an increased affinity to be harmed, particularly in areas of intersections (like chimneys), at covings and cullis as well as special units on the top floor (like dormers, transverse gables). Flat roofs, roof terraces and balconies, on the other hand, are more frequently damaged because of an unhindered surface distribution intruding rainwater. Amongst the soilcontacted elements, external walls as well as bottom plates and soil-covered ceilings of underground garages show characteristic damages. Refurbished old buildings erected between 1870 and 1945, by contrast, show much more damage in later installations on the top floor (dormers, roof terraces) and on soil-contacted external walls.

\subsection{Development of a component-related research approach}

The classification of building components and of whole buildings, respectively, with regard to their vulnerability to heavy rain depends on a number of structural as well as administrative framework conditions. Unlike other environmental factors such as hail or flooding, heavy rain does only slight damage to, intact buildings which are free of defects. During the ex-post evaluation of damage cases, it could be established that building damages usually occur when rainwaters infiltrate the construction through existing, local hot spots of the fabric. That is the reason why the vulnerability of components and buildings to heavy rain events is mainly characterized by the prevailing risk of construction defects. The assessment of the vulnerability of buildings to heavy rain therefore follows an approach that considers construction components. Its focus is on the identification of sensitive constructions and detailed solutions.

Furthermore, the possible magnitude of the damages or the intensity of damages, respectively, as well as the maintenance costs resulting from that are relevant criteria of evaluation. As Figure 2 shows, quality requirements of the design, construction and maintenance as well as the external conditions at the building site need to be taken into consideration when assessing the vulnerability.

The vulnerability of the whole building can be significantly influenced through each relevant construction element of the fabric (Fig. 2: construction elements 2.1 to 2.5) and through the building services (2.6). Therefore, it is necessary to establish the specific damage affinity for each individual element and for each building component, respectively, separately. The weighting of the individual vulnerabilities for each element follows on the basis of the amount of damage to be expected, in connection with the likely costs of refurbishment.

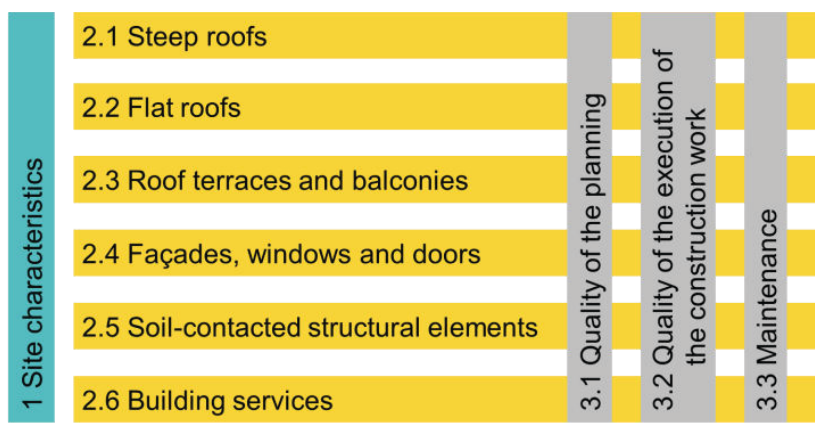

Figure 2. Evaluation scheme for the physical vulnerability of buildings exposed to heavy rain.

The influence of planning and execution on the vulnerability of construction elements and buildings is verifiably high. It is up the building planners to work out important requirements of the building construction. Thus, there are possibilities, to reduce the vulnerability of constructions by choosing sound structures, suitable materials and detailed solutions. When, on the other hand, no such detailed requirements are worked out beforehand, the results often include scenarios such as: important building elements are not properly thought out during the planning stage and the companies in question implement 
their own, more or less professional solutions. Connections of construction details as well as interfaces between different trades are particularly vulnerable areas. In addition, site-specific factors such as the surrounding structures, climactic conditions (design rain intensity, winddriven rain load), the site's altitude as well as the consistence of the soil are taken into consideration, too.

\subsection{Method of classification}

By applying this approach, basically favourable framework conditions can be separated from critical ones, which allows for the identification of existing deficits. In order to visualise the results and to indicate a concrete need for action, the established degree of vulnerability is shown in a diagram for each examined building element. The outcome of the entire building is depicted, too, with the weighting of the individual components taking into consideration all the important framework conditions.

The evaluation of all damage cases which were examined shows that a long period of precipitation plus complex connections of construction details have contributed very much to damage. This is why the focus must be on such measures of adaptation that lead to a quick, safe and direct drainage of rainwater. The economic efforts required to do that can be established and compared to the possible reduction of the building's vulnerability. As a result of the survey, there is now an instrument to establish the cost/benefit ratio of constructional options for action for the adaptation of constructions and buildings against heavy rain impacts.

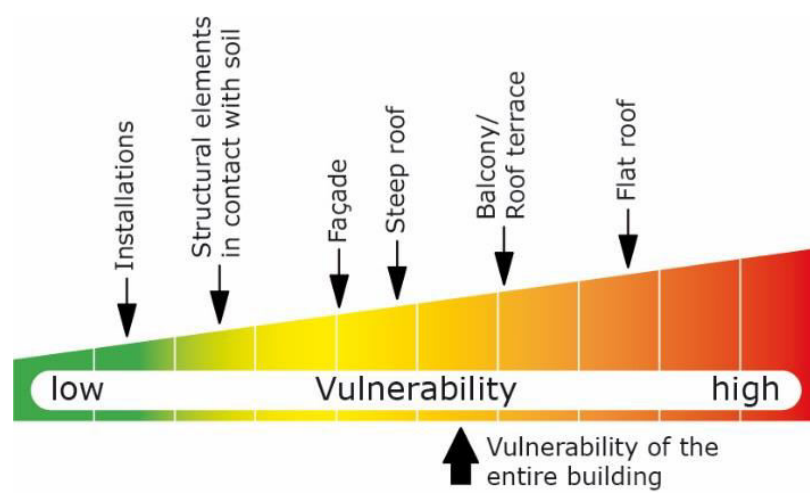

Figure 3. Physical vulnerability of building components exposed to heavy rain.

\section{Urban pluvial flooding}

This study presents the methodology as well as results of a simulation of flood damage costs of residential buildings caused by sewer flood in the centre of the city of Dresden, Germany. The objective of this study is to calculate potential damage to buildings by combining a hazard data based on hydro-dynamic modelling of sewer overflows with vulnerability and risk analysis. This analysis is performed using the GIS-based impact model Integrated Spatial Vulnerability and Risk Assessment Tool (IVART). The results are presented in statistics, risk maps, and risk curves.
A general methodology has been developed for analyzing flood vulnerability of properties which uses a synthetic approach for the calculation of flood damage. Implemented in the Integrated Spatial Vulnerability and Risk Assessment Tool (IVART), hydraulic modelling results are spatially interlinked with detailed information on the physical vulnerability of buildings (Neubert et al. 2014).

The identification and classification of buildings is realized using GIS and remote sensing data. Based on this, a building typology is created including urban structure types (UST) and building age groups. Based on refurbishment costs specific depth-damage functions are derived synthetically for all building types describing the degree of damage depending on different water depths due to surface or ground water flooding. The IVART model combines hydraulic modelling results representing the flood hazard, a dataset of typified geo-referenced buildings, and synthetic depth-damage functions determining potential impacts to building types due to flooding representing the vulnerability.

IVART calculates the exposure in form of potential damage costs for each building with its site-specific water depth. Results are risk maps for current or future situations with both reliable damage estimates and high spatial resolution. Outcomes can be aggregated for any spatial region of interest. The results allow to derive risk curves or to carry out (spatial) statistical analyses as well as risk analyses and cost-benefit analyses.

For the case study area of the inner city of Dresden a detailed hydraulic modelling result was kindly provided by the company ITWH (Institut für technischwissenschaftliche Hydrologie GmbH, Dresden). The used modelling approach incorporates a high resolution laser scanner digital surface model (DSM) as well as sewer system specifications. A 50-year rainfall with duration of 60 minutes for a future projection (2071-2100) with an height of $51.8 \mathrm{~mm}$ precipitation formed the basis (compared to a precipitation height of $47.6 \mathrm{~mm}$ for the reference period 1961-1990).

The damage calculation combined the maximum flood water depth per building with the building typespecific depth-damage functions. For every building polygon, the building losses were calculated using spatial combination algorithms implemented in the GIS-based IVART. The maximum water depth is reached at varying points of times at different locations. The total damage simulated for the modelled precipitation event in the study area reached 49 Million EUR. Maps of the area visualize the affectedness of buildings as well as the occurring potential damage per object.

Currently, IVART is being extended to model damage to buildings due to further impacts, like hail, heavy rain, storm, snow or summer heat will be considered in future. These impacts are likely to raise their intensity or occurrence frequency under a changing climate. It is further intended to include damage to other receptors than built- 
up areas, e.g. vegetation (i.e. drought impact) to extend the approach for regional analysis. Results will be incorporated in web-based spatial decision support systems (WebSDSS).

The approach has been applied in several national and international research projects with case studies in the Elbe River Basin (Germany), Manchester (UK) and Valencia (Spain). As a result of these applications, the model is also capable to consider the effects of flood precaution and defense measures (i.e. dry proofing, wet proofing, and avoidance). Methodological representation of the damage processes seems to be a sound basis for model simulations of the flood vulnerability of built-up areas under conditions of future land-use and climate change.

\section{Conclusion}

Heavy rain impacts on buildings already cause a multitude of different damage scenarios in the present situation. Trend analyses from the field of climatology suggest that heavy rain events will occur a lot more often and on a much bigger scale in different regions in Germany in the future. Since these events occur on a local level and since building damages occur infrequently and unexpectedly, damages caused by heavy rain events have so far often not been noticed as "accumulated damage events" of a regional or supra-regional importance, unlike floods, tornadoes or significant hail events.

Based on detailed damage analysis triggered by heavy rains in the region of Dresden, the authors of this study are able to give an overview of the most frequently affected construction elements and the most important damage scenarios, damage mechanisms and damage causes. The provided overview is not yet statistically sound, but it is very precise in terms of building construction. As a result, it is now possible to deduce what is of particular relevance when it comes to the vulnerability of buildings to heavy rain impacts, and to what extent a classification of this vulnerability is possible in the future.

In the future, more intensive heavy rain impacts can be considered as part of engineering planning algorithms and testing methods by using changed design rain intensities or wind-driven rain loads, respectively, when planning or assessing roofs, roof sealing, drainage facilities, façades, or windows and doors. In addition, the authors have introduced a testing method in order to assess the vulnerability of the building's fabric, including the distinction of major constructions and critical framework conditions.

Future work in the field of heavy rain impacts on buildings should elaborate on the assessment of damage cases amongst existing buildings and systematize the results. As for the classification of vulnerabilities, it will be of primary importance to integrate individual parameters in order to develop a quantifiable evaluation; some concepts have already been outlined. Finally yet importantly, the role that construction quality as well as care and maintenance play for the vulnerability of buildings and constructions must be discussed, too.

\section{Acknowledgements}

The presented work is based on the project REGKLAM (Development and Testing of an Integrated Regional Climate Change Adaption programme for the Model Region Dresden) which forms part of the KLIMZUG agenda (Managing Climate Change in the Regions for the Future). We are indebted to the German Federal Ministry of Education and Research (BMBF) for their financial support (Project No. 01 LR 0802).

\section{References}

Bundesministerium für Umwelt, Naturschutz und Reaktorsicherheit (Ed.) (2008). Deutsche Anpassungsstrategie an den Klimawandel. Berlin, pp. 78.

Bernhofer C., Matschullat J. and A. Bobeth (Ed.) (2009). Das Klima in der REGKLAM-Modellregion Dresden. REGKLAM Publikationsreihe, Heft 1. Berlin: RhombosVerlag, pp. 117.

Bernhofer C., Matschullat J. and Bobeth A. (Eds.) (2011). Klimaprojektionen für die REGKLAM-Modellregion Dresden. REGKLAM Publikationsreihe, Heft 2. Berlin: Rhombos-Verlag, pp. 112.

Franke J. and Bernhofer C. (2009). A method for deriving a future temporal spectrum of heavy precipitation on the basis of weather patterns in low mountain ranges. Meteorological Application, Vol. 16, pp. 513-522.

DAfStb (Ed.) (2003). Wasserundurchlässige Bauwerke aus Beton. Deutscher Ausschuss für Stahlbeton (DAfStb). Berlin: Beuth-Verlag.

DIN 1986-100 (05/2008). Entwässerungsanlagen für Gebäude und Grundstücke. Teil 100: Bestimmungen in Verbindung mit DIN EN 752 und DIN EN 12056. Berlin: Beuth-Verlag, pp. 82-85.

DWD (Ed.) (2005). KOSTRA-DWD-2000. Starkniederschlagshöhen für Deutschland (1951-2000). Grundlagenbericht. Department of Hydrometeorology. Offenbach am Main: Deutscher Wetterdienst (DWD), pp. 32.

DIN 4108-3 (07/2001 including correction 04/2002). Thermal protection and energy economy in buildings Part 3: Protection against moisture subject to climate conditions - Requirements and directions for design and construction. Berlin: Beuth-Verlag, pp. 10-13.

DIN 18055 (10/1981). Windows - Air permeability of joints, water tightness and mechanical strain - Requirements and testing. Berlin: Beuth-Verlag.

DIN 18531 (05/2010). Waterproofing of roofs - Sealings for non-utilized roofs - Part 1-4. Berlin: Beuth-Verlag. 
DIN 18195-5 (12/2011). Waterproofing of buildings Part 1-5. Berlin: Beuth-Verlag.

DIN EN 12056-3 (01/2001). Gravity drainage systems inside buildings - Part 3: Roof drainage, layout and calculation. Berlin: Beuth-Verlag.

DIN 1986-3 (11/2004). Drainage systems on private ground - Part 3: Specifications for service and maintenance. Berlin: Beuth-Verlag, pp. 14-16.

DIN 18355 (09/2012). German construction contract procedures (VOB) - Part C: General technical specifications in construction contracts (ATV) - Joinery. Berlin: Beuth-Verlag.

DIN EN 12208 (06/2000). Windows and doors - Watertightness - Classification. Berlin: Beuth-Verlag.

DIN EN 12154 (06/2000). Curtain walling - Watertightness - Performance requirements and classification. Berlin: Beuth-Verlag.

MNI (Ed.) (2002). Verletzbarkeitsanalysen ex-Post an bestehenden Gebäuden in der Modellregion Dresden. Research study on behalf of the Leibniz Institute of Ecological Urban and Regional Development (IOER). Dresden: MNI Dresden-Diplomingenieure für Bauwesen. unpublished.

Neubert M., Naumann T., Hennersdorf J., Nikolowski J. (2014). The Geographic Information System-based flood damage simulation model HOWAD. J. Flood Risk Manag., DOI: 10.1111/jfr3.12109

RAL-Gütegemeinschaft Fenster und Haustüren e.V. (Ed.) (2006). Leitfaden zur Planung und Ausführung der Montage von Fenstern und Haustüren. 4. Auflage. Frankfurt am Main: RAL-Gütegemeinschaft Fenster und Haustüren e.V.

Zimmermann G., Ottomann A., Klopfer H. and Soergel C. (2008). Wasserschäden - Schadensfälle, Leckortung, Bautrocknung, Verantwortlichkeit. Stuttgart: Fraunhofer IRB-Verlag, pp. 203.

ZVDH (Ed.) (2011). Deutsches Dachdeckerhandwerk Regelwerk. Zentralverband des Deutschen Dachdeckerhandwerks (ZVDH), Fachverband Dach-, Wand- und Abdichtungstechnik e.V. Köln: Verlag Rudolf Müller.

ZVSHK (Ed.) (2009). Richtlinien für die Ausführung von Klempnerarbeiten an Dach und Fassade (Klempnerfachregeln). St. Augustin: Zentralverband Sanitär Heizung Klima (ZVSHK). 